Jurnal Teknologi, 37(D) Dis. 2002: 19-30

(C) Universiti Teknologi Malaysia

\title{
BLUETOOTH TRANSCEIVERS FOR FULL DUPLEX COMMUNICATIONS IN MOBILE ROBOTS
}

\author{
S. H. CHOO ${ }^{1}$, SHAMSUDIN H. M. AMIN ${ }^{2}$, N. FISAL ${ }^{3}$, C. F. YEONG ${ }^{4}$, \\ \& J. ABU BAKAR ${ }^{5}$
}

\begin{abstract}
This work explores the implementation of Bluetooth technology in mobile robots. The mobile robot has the capability to move around autonomously using complicated and powerful algorithm. The algorithms are stored in the master as the server. All sensor readings from the mobile robot will be transmitted to the master and processed. Then, command or instruction for further action is transmitted from the server to the mobile robot in a bi-directional full duplex communication mode. Hence, the main "brain" is in the server instead of the mobile robot. This paper will focus on the interfacing between Bluetooth transceiver and Handy Board MC68HC11 micro-controller of mobile robot. For common case, a receiver and transmitter are needed for each device (robot and control unit), but with Bluetooth technology, only two Bluetooth transceivers are needed to achieve full duplex connection. This project has provided a Bluetooth enabled mobile robot. The mobile robot can be controled wirelessly via Bluetooth transceiver.
\end{abstract}

Keywords: Bluetooth Technology, bi-directional, full duplex, autonomously, Handy Board

\begin{abstract}
Abstrak. Projek ini mengeksplotasi penggunaan Teknologi Bluetooth dalam robot mudah alih. Robot mudah alih mempunyai kebolehan untuk bergerak secara automasi menggunakan algoritma yang rumit dan canggih. Algoritma disimpan dalam sebuah komputer sebagai tuan dan juga "server". Segala bacaan penderia daripada robot mudah alih akan dihantar kepada tuan dan diproses. Kemudian, arahan untuk langkah seterusnya akan dihantar dari "server" kepada robot mudah alih dalam mode komunikasi dua hala dan dupleks penuh. Maka, "otak" utama berada di "server" dan bukannya pada robot mudah alih. Kertas ini akan memfokus pada perantaraan muka antara Bluetooth transceiver dan Handy Board MC68HC11 mikro pengawal pada robot mudah alih. Untuk kes biasa, satu penerima dan penghantar diperlukan untuk setiap alat (server dan client) masingmasing, tetapi dengan Teknologi Bluetooth, hanya dua Bluetooth transceiver diperlukan untuk mencapai perhubungan dupleks penuh. Projek ini telah menghasilkan robot mudah alih dengan kebolehan Bluetooth. Robot tersebut boleh dikawal secara "wirelessly" melalui Bluetooth transceiver.
\end{abstract}

Kata kunci: Teknologi Bluetooth, dua hala, duplex penuh, automasi, Handy Board

${ }^{1}$ Department of Mechatronics and Robotics, Faculty of Electrical Engineering, Universiti Teknologi Malaysia, 81310 UTM Skudai, Johor, Malaysia. 07-5535793. ober78@hotmail.com.

${ }^{2}$ Department of Mechatronics and Robotics, Faculty of Electrical Engineering, Universiti Teknologi Malaysia, 81310 UTM Skudai, Johor, Malaysia. 07-5535319. sham@fke.utm.my

${ }^{3}$ Department of Telematic and Optical Communication Engineering, Faculty of Electrical Engineering, Universiti Teknologi Malaysia, 81310 UTM Skudai,Johor, Malaysia. 07-5505194. sheila@fke.utm.my

${ }^{4}$ Department of Mechatronics and Robotics, Faculty of Electrical Engineering, Universiti Teknologi Malaysia, 81310 UTM Skudai, Johor, Malaysia. 07-5535793. cfyeong@hotmail.com

${ }^{5}$ Ericsson Sdn. Bhd., Wisma Ericsson, Jln SS7/19, Kelang Jaya, 47301, Petaling Jaya, Selangor Darul Ehsan, Malaysia.Jaafar.abu-baker@emy.ericson.se 


\subsection{INTRODUCTION}

Nowadays, there are a lot of on-going and completed projects on wireless mobile robot control. With wireless communication, mobile robots can connect to other mobile robots and PC. Thus, mobile robots can be controlled wirelessly via a computer or even constructing a multi-agent robot system. The mobile robots can also be autonomous if the algorithm is downloaded directly into the memory of the mobile robot. One common form of wireless technology is the utilization of radio frequency $(\mathrm{RF})$ transmitter and receiver on mobile robots. However, there are a few limitations. One such limitation is that the communication is only one direction and half duplex. The algorithm written is limited by the memory available on the mobile robot. Thus, only simple algorithms can be written. Infrared Data Association (IrDA) is another form of cheap wireless technology but requires a line-of-sight connection to establish communication in a shorter range of $1 \mathrm{~m}$ [1]. This is not practical for an autonomous mobile robot. Due to these factors, this project tries to explore the possibility of substituting RF transceiver and infrared with Bluetooth technology for wireless control of mobile robots.

Currently, the Bluetooth Special Interest Group (SIG) is driving development of this technology and bringing it to market. The SIG includes promoter companies Ericsson, 3Com, IBM, Intel, Lucent, Microsoft, Motorola, Nokia and Toshiba, and more than 2000 Adopter/Associate member companies comprised of leaders in the telecommunications, computing, and network industries [1]. A scant number of Bluetooth products are currently in the market, and they have limited uses: headsets, cell phones, printers and computers. One such example is the Ericsson T68.

\subsection{BLUETOOTH TECHNOLOGY}

Bluetooth is a new technology for wireless connectivity. It is a universal radio interface in the $2.45 \mathrm{GHz}$ frequency band that enables portable electronic devices to connect and communicate wirelessly via short-range, ad hoc networks. The Bluetooth system is based upon cheap, power-efficient radio chip small enough to fit inside any electronic device or machine. The chip provides local connectivity and creates a micro-scale web.

\subsection{Bluetooth Specification}

Bluetooth Specification defines the requirements ensuring interoperable operation between Bluetooth transceiver from different manufacturers. There are two major areas in Bluetooth specifications: the radio and protocol definitions (protocol stack), and the compliance requirements [2]. Figure 1 outlines the application framework in the context of the radio and protocol stack. 


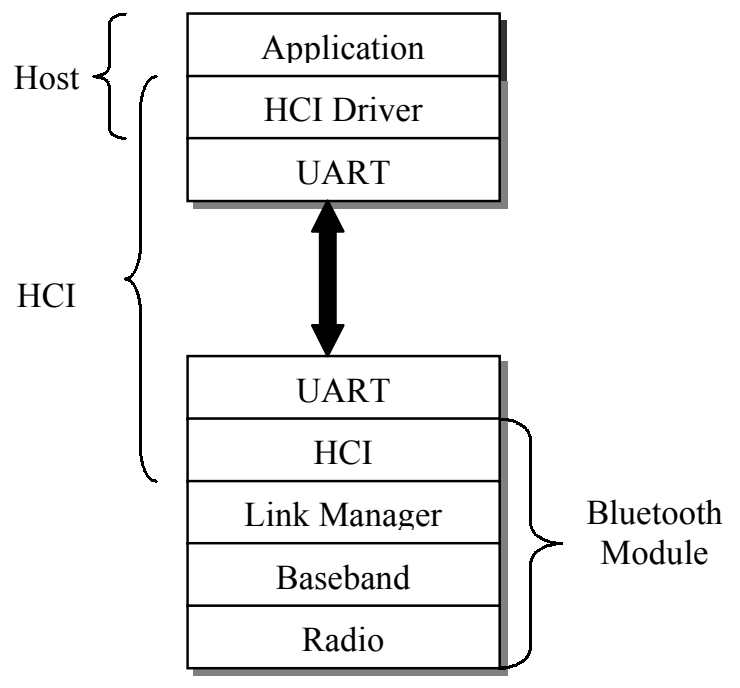

Figure 1 Bluetooth protocol stack

There are four basic parts to any Bluetooth system: a radio $(\mathrm{RF})$ that receives and transmits data and voice, a baseband or link control unit that processes the transmitted or received data, link management software that manages the transmission and supporting application software [3].

The Bluetooth radio is a short distance, low-power radio operating in the unlicensed spectrum of 2.4 gigahertz $(\mathrm{GHz})$ and using a nominal antenna power of 0 $\mathrm{dBm}$. At $0 \mathrm{dBm}$, the range is ten meters, meaning equipment must be within 10 meters of each other (about 33 feet) to communicate using the Bluetooth standard. Optionally, a range of 100 meters (about 328 feet) may be achieved by using an antenna power of $20 \mathrm{dBm}$. Data is transmitted at a rate of up to 1 megabit $(\mathrm{Mb})$ per second, maximum. But communication protocol overhead limits the practical data rate to $721 \mathrm{Kbits}$ per second [3]. Modulation is GSFK (Gaussian Frequency Shift Keying). Binary one is represented by a positive frequency deviation, and binary zero is represented by a negative frequency deviation [4].

Baseband is the hardware that turns the radio signals (transmit/receive) into a digital form that can be processed by the host application. In other words, it can convert the digital or voice data into a form that can be transmitted using a radio signal, according to a protocol that allows it to be decoded once it is received. The baseband processor handles all the tasks such as converting data from one form to another (e.g., voice to digital data), compressing it, putting it into packets, taking it out of packets, assigning identifiers and error correction information and then reversing the process for data that is received. In Bluetooth, the baseband function is called the Link Controller.

The Bluetooth link is the method of data transmission to be used. The Bluetooth standard supports two link types, Synchronous Connection Oriented (SCO), used 
primarily for voice communications and Asynchronous Connectionless (ACL) links for packet data. Each link type supports sixteen different packet types that are used based on the application. Any two devices in a Bluetooth system may use either link type and may change link types during a transmission.

Above the Baseband layer is the Link Manager (LM) [3]. The Link Manager is software that runs on a microprocessor and manages the communication between Bluetooth transceiver. Each Bluetooth transceiver has its own Link Manager that discovers other remote link managers and communicates with them to handle link setup, security, authentication, configuration and other protocols. In order to execute these commands peer LMs send PDU (Protocol Data Units) to each other, containing link set-up, security and control information. LM PDUs received from the Baseband are filtered out by the LM on the receiver end and are not propagated to higher layers. All layers up to the LM layer are implemented in Bluetooth hardware. Higher protocols find their implementation in software running on a Bluetooth host [3].

To be able to access all the SAPs (Service Access Points) of the LM protocol and to be able to exchange data with the Baseband layer, the HCI (Host Controller Interface) protocol is used to provide an interface between the Bluetooth hardware and a host, using a physical connection between them. The connection can either be a USB, a RS-232 or an UART. This is the area of our focus, where our current work involves writing the HCI for communication between Handy Board and Bluetooth Transceiver. It is initially written in Visual Basic for testing and then in Interactive C to be downloaded into the Handy Board for mobile robot control.

The L2CAP (Logical Link Control and Adaptation Protocol) is the transport layer of the protocol stack. This protocol supports higher-level protocol multiplexing, packet segmentation and reassembly.

\subsection{Profiles}

Since Bluetooth can be used in wide range of applications, the interoperability is only desirable in certain type of application. Using profiles simplify the implementation since the product only has to be fully compatible with the profile it is qualified for. The cordless phone may not need to talk to printer or an industrial sensor. One transceiver may support several profiles. The profiles are used for defining a common user experience [5].

\subsection{PROJECT DESCRIPTION}

The main objective of this project is to interface Bluetooth transceiver and Handy Board (mobile robot) and establish a wireless connection between mobile robot and PC. In order to prove the connection is bi-directionally, $\mathrm{PC}$ must be able send steering data to the Handy Board MC68HC11 and also be able to receive sensor reading from Handy Board via Bluetooth transceiver. 
The PC that acts as a master is connected to Bluetooth transceiver through serial port. Another Bluetooth transceiver is connected to Handy Board on mobile robot. First, both PC and Handy Board must initialize the Bluetooth transceiver. ACL data packet containing instruction for mobile robot will be sent to local Bluetooth module from the PC. Then data is transmitted over the air to the Bluetooth transceiver connected to the Handy Board in Piconet network. The data is sent to Handy Board in the payload of ACL data packets over the physical connection between the Handy Board and Bluetooth transceiver using the HCI protocol. The Handy Board can extract the instruction to steer the motor mounted on the mobile robot.

During the navigation of the mobile robot; user from the PC was able to understand the surroundings of the robot after receiving sensors reading from the mobile robot. Thus, it enables a fast real time application and reaction.

\subsection{Hardware Components}

The hardware components used in this project are a mobile robot, two Bluetooth Application and Training Tool Kit from Ericsson and a PC.

The Bluetooth Application and Training Tool Kit is a platform, consists of a circuit board, which can easily be connected to the host computer with a UART (Universal Asynchronous Receiver Transmitter) or USB connection, which ensures ease of use and full Bluetooth data transfer speed. The tool kit has been developed by Ericsson and enables students in higher education to understand both the theory and applications of Bluetooth short-range radio communication. But the Bluetooth Application and Training Tool Kit did not support voice transfer, thus voice communication cannot be implemented between Mobile and PC.

The mobile robot used in this project is the UTM 'Aibot'. Figure 2 shows the picture of "Aibot". The mobile robot is built up from different hardware components. Two wheels are used for steering. These wheels are connected to two DC motors, which are controlled independently to steer the mobile robot. Two castors are mounted in the back and front underneath the frame of the mobile robot. It is used to support the mobile robot to achieve the carefree movements. A Handy Board is placed on top of the mobile robot.

The intelligent part that controlled mobile robot is the Handy Board [6]. It forms the brain of the mobile robot. It controls the DC motors, reads the sensors information and also control the interfacing with Bluetooth transceiver. The Handy Board is based on the 52-pin Motorola MC68HC11 microcontroller, and includes $32 \mathrm{~K}$ of battery-backed static RAM, four outputs for DC motors, a connector system that allows active sensors to be individually plugged into the board, an LCD screen, and an integrated, rechargeable battery pack [6]. Figure 3 shows picture of Handy Board. 


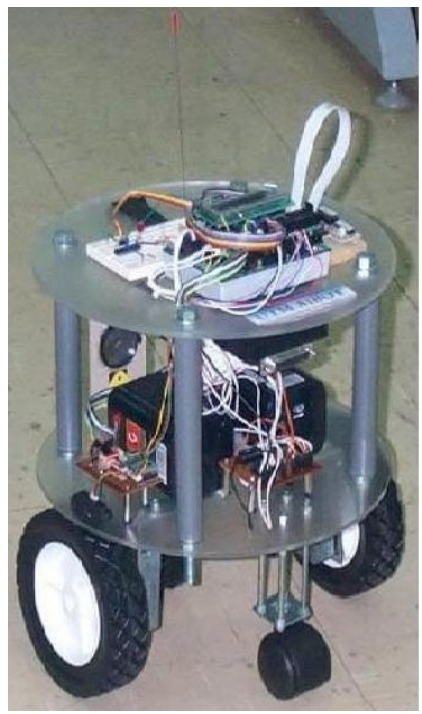

Figure 2 UTM 'Aibot'

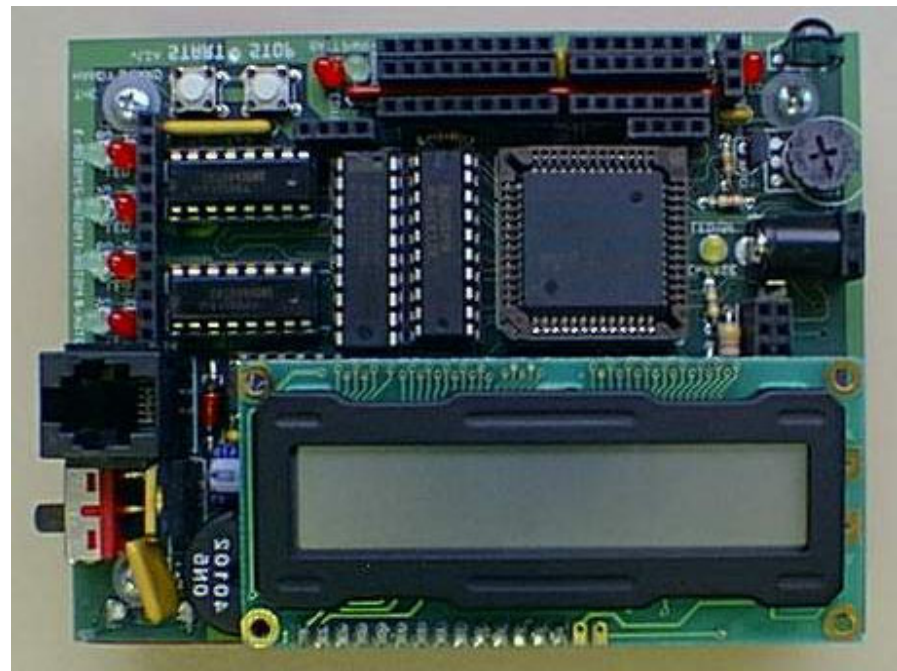

Figure 3 Handy board

\subsection{Host Controller Interface}

Ericsson Bluetooth transceiver is connected to Handy Board through a UART connection. The HCI protocol is used on this physical connection to make it possible for the Handy Board to interface with Bluetooth transceiver. Handy Board (Host) operates the Bluetooth module using command packets, which are confirmed with an event packet telling if the command was successful or not [7]. Because of the default baud rate of Bluetooth transceiver is $57,600 \mathrm{bps}$, but the highest baud rate of Handy 
Board is 9,600 bps; the baud rate of Bluetooth module have to be modified order to interface with Handy Board [3]. Thus, the baud rate of Bluetooth transceiver is changed with Ericsson specific HCI command (HCI_Ericsson_Set_Uart_Baud_Rate-changing baud rate command is vendor specific) [3]. Figure 4 shows the GUI for changing baud rate of Bluetooth transceiver to $9,600 \mathrm{kbps}$.

HCI command packets can initiate LM procedures, initiate baseband procedures

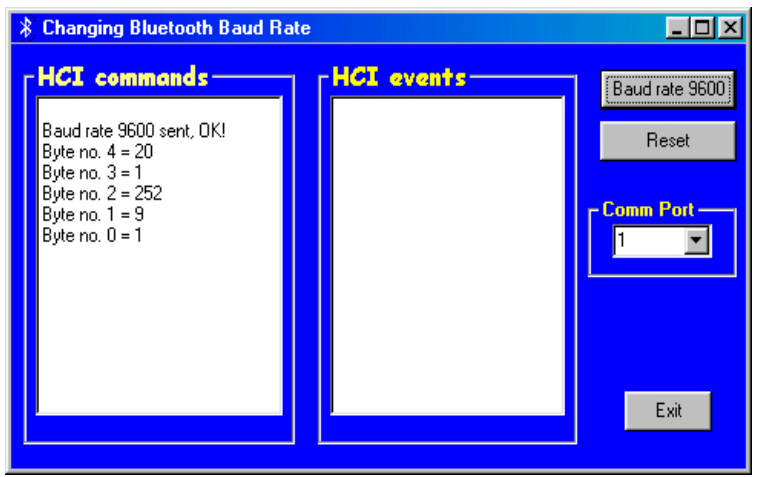

Figure 4 A simple program for changing Bluetooth kit baud rate

and control overall working of the Bluetooth transceiver [8]. User data packet contains ACL link data, which the Baseband transfers over the piconet [8]. HCI packets sent from the Bluetooth transceiver to mobile robot either contains user data received from the PC or event data. HCI event packets are sent back to the Handy Board after the Handy Board has sent a command packet. Such event packets contain result of the command. Event packets are also sent when event occurs in the piconet, for instance after a connection has been made.

To send command to Bluetooth transceiver, Little Endian format [9] is used. Many commands have been defined, a few of them are HCI_Reset, HCI_Set_Filter and HCI_read_BD_ADDR. These commands are tested on Bluetooth transceiver with a simple application written in Visual Basic. A HCI event packet is send back to indicate the result of $\mathrm{HCI}$ command.

ACL data packets are used to exchange data between the Handy Board and the PC. The data packets are defined for ACL data types. The format of the ACL data packet is shown in Figure 5.The size of Data Total Length field is 2 bytes long, thus theoretically maximum size of data is 65535 bytes. But most Bluetooth module will not have buffer large enough to receive this size packet. Anyway, every Bluetooth module and host is required to support at least 255 bytes of data [10]. ACL data packet can be sent only after the connection between Bluetooth transceivers was established. For this project, ACL data packet containing instruction information from $\mathrm{PC}$ and sensor reading from mobile robot. 


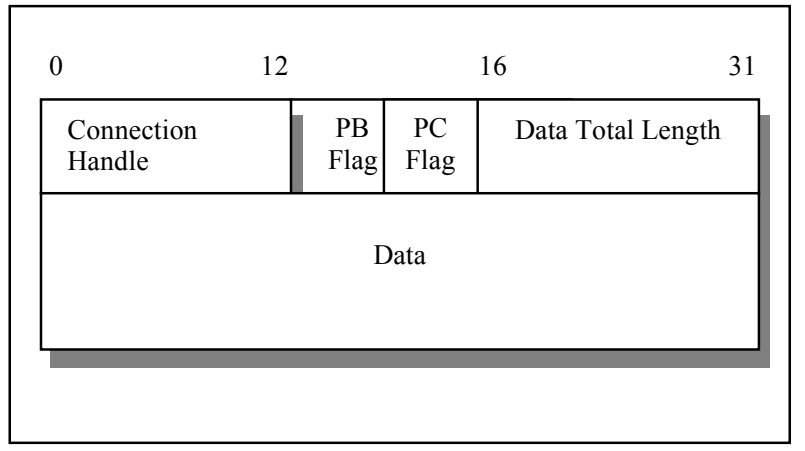

Figure 5 ACL data packet

\subsection{Point to Point Connection}

Bluetooth point-to-point connection is done through the Host Controller Interface (HCI) of Bluetooth module. The host presents commands to the HCI and receives events back from HCI of Bluetooth module. Through HCI commands, the mobile robot (Host B) set the Bluetooth module attached to it in Page Scan Mode listening for connection request, while the Host (PC) will set it Bluetooth module to Page Mode searching for other Bluetooth transceiver. Mobile robot will act as a slave because Bluetooth transceiver is in Page Scan Mode waiting for connection request. On the other hand, Page Mode means asking for a connection from another host. The PC Bluetooth module will act as master when it is set in this Page Mode. Figure 6 shows protocol to make point to point connection using HCI commands.

\subsection{Software Design}

Software has to be written for the PC and Handy Board in order to make mobile robot Bluetooth enable. Both the PC and Handy Board software can initialize the Bluetooth transceiver. The software design for the system is divided into several parts.

- Communication between PC with Bluetooth transceiver:-

$\mathrm{PC}$ is able to detect and communicate with local Bluetooth transceiver using software [11]. With Active-X in Visual Basic 6.0, this can be achieved. However, the programmer is not able to access to the HCI, L2CAP or SDP. These layers are all hidden away from the programmer. Figure 7 shows the developed GUI for making connection between PC (Host A) and Mobile robot (Host B).

- Communication between mobile robots (Handy Board ) with Bluetooth transceiver:-

The main challenge of this project is to write the Host Controller Interface (HCI) program in Interactive $\mathrm{C}$ for the Handy Board to make possible the communica- 


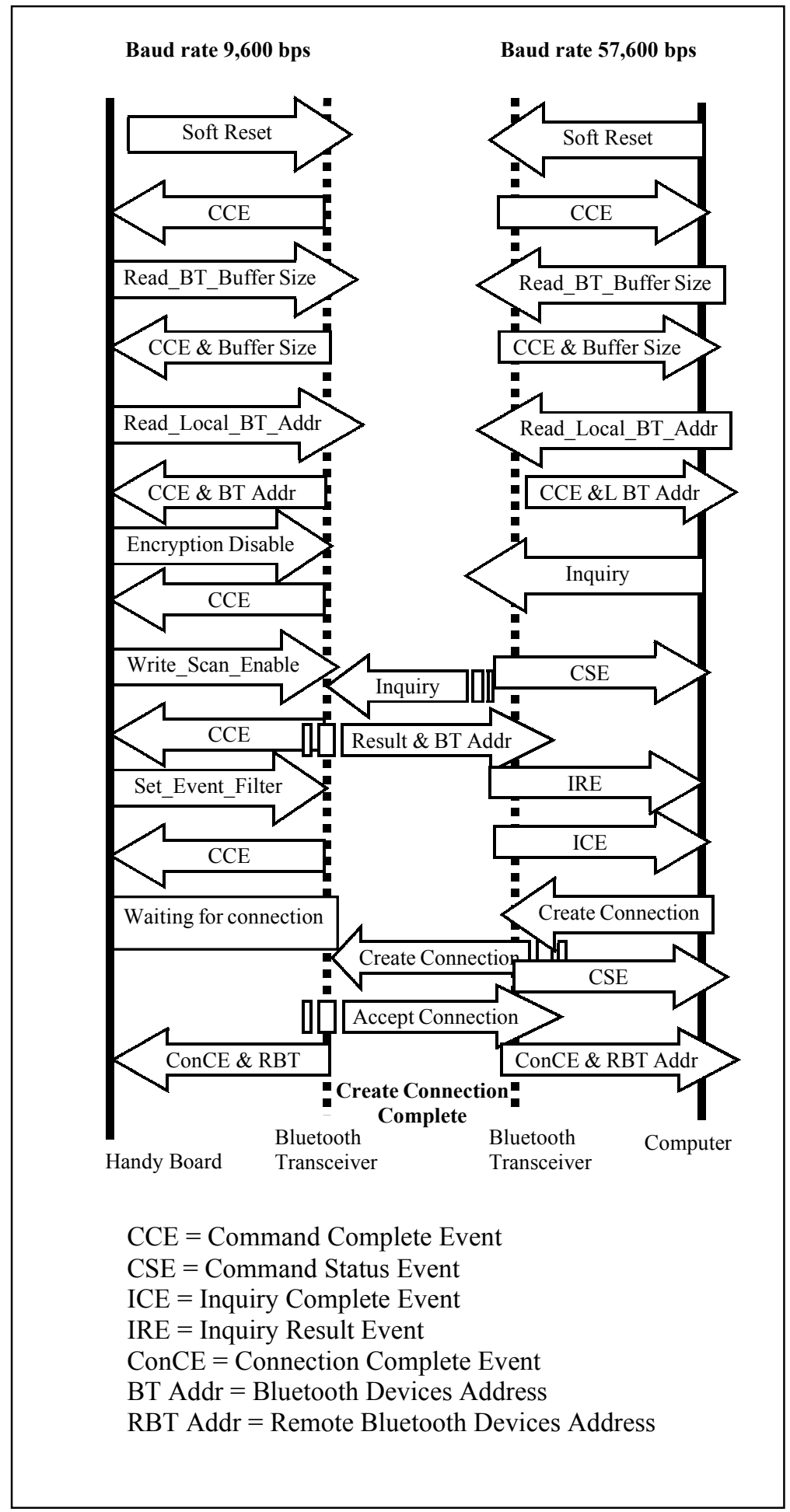

Figure 6 Procedure to create connection 


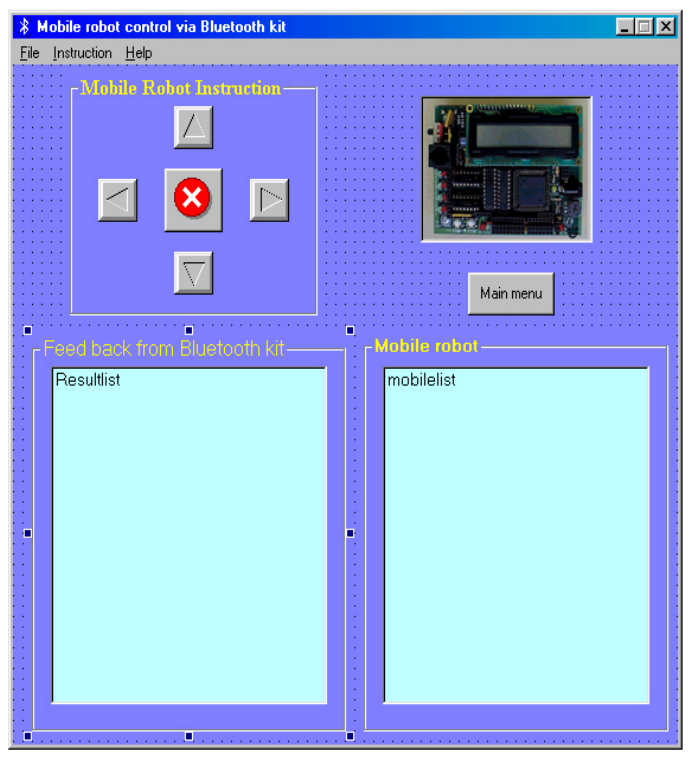

Figure 7 GUI for making connection with mobile robot

tion with the Bluetooth transceiver.

- Algorithm on the Host Computer:-

An Algorithm for controlling mobile robot via Bluetooth transceiver is written. The PC should be able to control Bluetooth transceiver attached to it, by sending $\mathrm{HCI}$ command packet and receiving HCI event packet. It also able to send steering data according to user need and display the sensor reading from mobile robot. A GUI (Figure 8) is design to allow manual and automatic control of the mobile robot.

- Algorithm on the mobile robot (Handy Board):-

A program has been written in Interactive $\mathrm{C}$ to handle the $\mathrm{DC}$ motors, sensor readings and also interfacing between Bluetooth transceiver.

\subsection{SUMMARY}

The aim of this work is to connect Bluetooth transceiver and mobile robot (Handy Board) for bi-directional communication. It provides a simple control system for Bluetooth enabled mobile robot. With Bluetooth extremely fast developed technology, it will decrease cost and space of bi-directional communication mobile robot. Based on tests carried out on the mobile robot and Bluetooth transceiver, wireless control of mobile robot using Bluetooth technology is a feasible idea. This work had successfully interfaced Bluetooth transceiver onto Handy Board MC68HC11 of the mobile robot. 


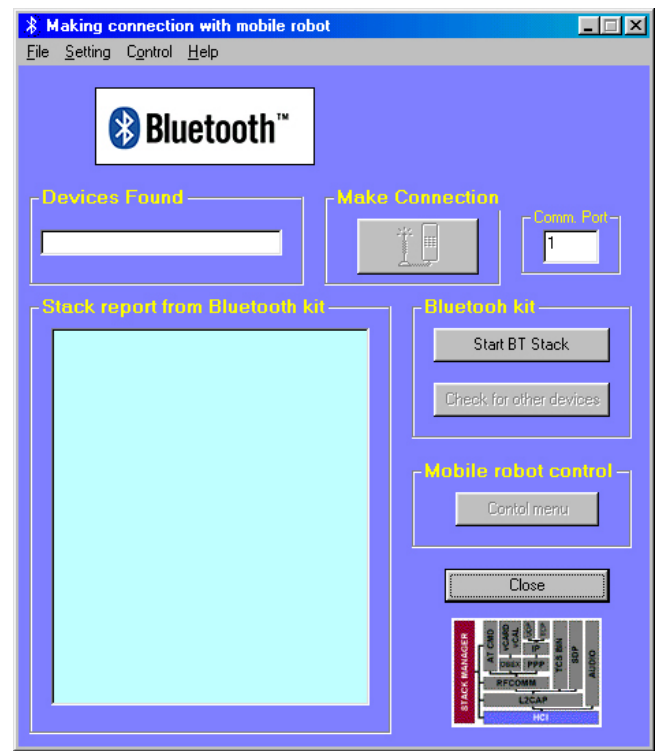

Figure 8 GUI for control the mobile robot and display sensor reading

\section{REFERENCES}

[1] Beginner Guide [Online] Available at http://www.ericsson.com/bluetooth/bluetoothf/beginnersg/

[2] Specification of the Bluetooth System v. 1.1 - Core [Online] Available at http://www.bluetooth.com/index.asp

[3] Atmel Bluetooth ${ }^{T M}$ Solution Backgrounder, [Online] Available at http://www.atmel.com

[4] Visuri, P., R. Nilsson. 2000. Developing a Bluetooth Test System. Thesis, Lund University, pp. 7-12.

[5] Sidenmark, M. 2000. Blue Id Access System using Bluetooth. Thesis, University of Karlskrona, pp. 7-15.

[6] Fred, G. M. 1999. The Handy Board Technical Reference. Massachusetts Institute of Technology.

[7] Olosson, P. 2000. Bluetooth for Sensor. Thesis, University of Karlskrona, pp. 24-30.

[8] Dijkstra, M., A. R. Martena. 2000. Radio Controlled Robot Car Using Ericsson Bluetooth Starter Kit. Thesis, University of Karlskrona/Ronneby, pp. 16-29.

[9] ERICSSON, ROK 101 008, Bluetooth PtP module datasheet, pp.15-18.

[10] Bray, J., C. F. Sturman. 1999. Bluetooth ${ }^{T M}$ Connect Without Cables. Prentica Hall PTR, pp. 115-126.

[11] The Bluetooth Site by Engineers for Engineers, [Online] Available at http://www.cstack.com 